\title{
An Assessment of the Services Quality of Palestine Higher Education
}

\author{
Aida Koni ${ }^{1}$, Khalim Zainal ${ }^{1}$ \& Maznah Ibrahim ${ }^{1}$ \\ ${ }^{1}$ Institute of West Asian Studies, National University of Malaysia, Selangor, Malaysia \\ Correspondence: Aida Koni, Institute of West Asian Studies, National University of Malaysia, Selangor, \\ Malaysia. Tel: 60-126-254-696. E-mail: aida.koni@yahoo.com
}

Received: November 15, 2012 Accepted: November 27, 2012 Online Published: December 16, 2012

doi:10.5539/ies.v6n2p33 URL: http://dx.doi.org/10.5539/ies.v6n2p33

\begin{abstract}
The history of the Palestinian universities is relatively recent; however their impact on the Palestinians case and wellbeing is undeniable. Today, almost forty years later the Palestinian universities like many higher education institutions in the region and worldwide tussle to fulfil the students' demands on education while trying to maintain high quality and relevant education. In Palestine; studies of higher education sector seems to focus primarily on easily quantifiable indicators such as teacher vs. students ratios and gender participation, while the assessment of educational services quality have not yet been explored and the assessment of higher education from the students' stands point is yet to be enhanced. Meanwhile; the literature is rich with scholars who emphasize that "service quality" is the key to achieve customers' satisfaction and loyalty. The applicability of service quality concepts and assessment models is becoming more acceptable within the higher education arena. This research presents an assessment of the services quality at two universities in the West Bank; Palestine utilizing the SERVQUAL gaps model and instrument for measuring students' satisfaction and behavioural intentions. The study wishes to assist the Palestinian universities administrative boards and stakeholders to create informed decisions with regards to the effectiveness of their educational policies. The results suggest that the "service quality" in Palestine universities is slightly unsatisfactory to the students and needs further attention.
\end{abstract}

Keywords: SERVQUAL, service quality, assessment, Palestinian University

\section{Introduction}

The 1980's witnessed an unprecedented interest in the service industry sector. The sector emerged as a fundamental pillar in modern economy and encouraged scholars such as Grönroos (1999) Buzzell and Gale (1987) and Bai and Liu (2002) to name a few, who emphasized that service quality have a direct and fundamental influence on customer loyalty. Cronin, Brady and Hult (2000) suggested that service quality affects customer loyalty indirectly by influencing the customers' satisfaction and perceived value (R. Zhang, Li and Y. Zhang 2010). On the other hand, the higher education sector in the Middle East region and worldwide has been rendered by societal, national, regional and global changes. These changes pertain to fierce competition over state fund, the age structure of the students and unprecedented increase in the number and models of newly established higher education institutions to fulfil the students demand on education (Chen 2012; De Jager and Gbadamosi 2010). The Palestinian universities are no exception.

The Palestinian Universities are relatively young; however their impact on the Palestinians' life, wellbeing and cause is undeniable. Today, almost forty years after they came to existence, the Palestinian universities like many higher education institutions in the region and worldwide tussle to fulfil the students' demands on education while trying to maintain high quality and relevant education. The review of the literature of higher education sector in Palestine suggests that most of the studies focus on easily quantifiable indicators such as teacher versus students' ratios, access to higher education and equity. These studies rarely assess the education quality from the students' standpoints nor assess the service quality.

The applicability and adaptation of the service quality concepts and assessment models into the higher education sector have attracted much attention in recent years; where many education institutions conceptualize them as a major goal to achieve (Temizer \& Turkyilmaz 2012). Astin (1993) noted that "related satisfaction levels and the students' perceptions of quality will determine student retention". He suggested the presence of "a direct association between student satisfaction and retention ... the strength of these associations and their prevalence across all measures suggest that one promising way to reduce an institution's dropout rate is to focus more 
attention on student satisfaction". Among the most well known models developed to measure the service quality in higher education is the service quality gaps model, mostly known as the "SERVQUAL model" by Parasuraman, Zeithaml and Berry (1985). The authors argued that each time a customer encounters a service; the customer judges the quality of the service in question against his/ her expectations. Therefore similar to the "service industry sector" any academic institution that attempts to evaluate the quality of its educational services should comprehend the expectations and perceptions of its prime customers beforehand, hence the students and exerts efforts to meet as closely as possible their expectations. This study presents an assessment of the service quality at two universities in the West Bank; Palestine utilizing an enhanced SERVQUAL instrument to measure students satisfaction and loyalty intentions.

\section{Literature Review}

\subsection{Service Quality in Higher Education}

Scholars have long contemplated over a universally accepted definition of services and service quality; however their task proved to be an uneasy one. Grönroos (1990: 27) defined services as

"Activities or a series of activities of more or less intangible nature that normally, but not necessarily, take place in interactions between the customer and service employees and/or physical resources or goods and/or systems of the service provider, which are provided as solutions to customer problems"

Zeithaml and Binter (1996:5) defined services, including educational services as "deeds, processes and performances". The difficulty to define services is attributed to the unique characteristics of the services which distinguish them from goods. These unique characteristics of services posed further challenges to scholars to assess the performance of the service sector. Services are described as intangible, heterogeneous, inseparable and Perishable. The review of the literature of service quality suggests that most of the definitions of service quality tends to be consumer- oriented (Kessler 1995). Lewis and Booms (1983: 100) defined service quality as a 'measure of how well the service level delivered matches the customer's expectations. Defining service quality in the context of higher education is no less elusive. Reeves and Bednar (1994) conclude that "the search for a universal definition of quality and a statement of law like relationships has been unsuccessful" and recommend that the definition of service quality in education should follow the general definitions of service quality. This encouraged the higher education community to adopt a few of the models that were developed originally to measure service quality in the private sector to investigate the service quality within the higher education setting (Lovelock 1981; Chua, 2004). Gatfield, Barker and Graham (2006) explored Australian and International students' perception of quality variables in an Australian higher education setting. The authors developed and used a scale comprised of 26 quality variables. Their findings revealed a hierarchy amongst the factors where "academic instruction" was the most critical aspect. De Jager and Gbadamosi (2010) studied the service quality and the students' intention to leave the university, trust in management of the university and the overall satisfaction with the university at two local higher education institutions in South Africa. The study revealed significant relationship between service quality in HE and other study variables - intention to leave the university; trust in management of the university and overall satisfaction with the university.

Parasuraman et al. (1988) defined service quality as "the extent of discrepancy between customers' expectations or desires and their perceptions" and operationalized this definition as the disconfirmation between customers' perceptions minus their expectations (SERVQUAL= Perceptions - Expectations). The authors proposed ten dimensions of service quality with five basic gaps to be analyzed and these are: Tangibility, Reliability, Responsiveness, Competence, Courtesy, Credibility, Cecurity, Access, Communication and Understanding the consumer. Their research was later refined leading to the development of the SERVQUAL scale which measures customers' perceptions of service quality. The original ten dimensions were later condensed into five dimensions and these are:

- Tangibles: Appearance of Physical facilities, equipment, personnel, and communication materials

- Reliability: Ability to perform the promised service dependably and accurately

- Responsiveness: Willingness to help customers and provide prompt service

- Assurance: Knowledge and courtesy of employees and their ability to convey trust \&confidence

- Empathy: Caring, individualized attention the firm provides its customers

The authors suggested that regardless of the service being studies, "Reliability is the most critical dimension while tangibles are the least". The instrument has been described as "tried and tested instrument which can be used comparatively for benchmarking purposes" (Brysland and Curry, 2001). The model was first adopted into 
the higher education context to measure academic library service quality by the Association of Research Libraries (ARL); and was called LibQUAL (Awan \& Mahmood 2011). The study of service quality in higher education utilizing the SERVQUAL instrument has been empirically tested over the past few years; and while some of these studies are conceptualized globally, others were concerned with testing the service quality instrument on the country level. Soutar and McNeil (1996) utilized a modified SERVQUAL instrument to test the students' views of the quality of academic and administrative services provided in an Australian university. Their study found the students to be quite satisfied with the quality of the academic units surveyed; although there were gaps in reliability, responsiveness, assurance, empathy, knowledge and communication however those were small in magnitude. Sahney, Banwet and Karunes (2004) studied students within selected educational institutions in India utilizing the SERVQUAL methodology. The authors later used the quality function deployment technique to identify the set of minimum design characteristics/quality components that meet the requirements of student as customers of the educational system. Tan \& Kek (2004) adopted an enhanced approach to measure the students' satisfaction at two local universities in Singapore utilizing the SERVQUAL instrument. Their approach involved the use of factors which concern the student services that are queried and surveyed using the SERVQUAL methodology within 76 different areas. Their results identified large gap scores at both universities for school authority and communicating with the university's management. The students' expectations were better met for university facilities and social activities at one of the two universities. In Malaysia, Shekarchizadeh, Rasli and Hon-Ta (2011) assessed the service quality perceptions and expectations of international postgraduate students studying in selected Malaysian universities utilizing a modified SERVQUAL instrument. Their study included 35 items distributed into five factors: professionalism, reliability, hospitality, tangibles, and commitment. The study concluded that the international postgraduate students attending five Malaysian universities have negative perceptions of education service quality in their universities, as students' expectations were not met in the performance of education services. The students were dissatisfied with the education service quality on all the five aforementioned quality factors. The authors attributed the students' dissatisfaction to the international students benchmarking the Malaysian universities to Western universities in America and Europe as a general class for higher education.

Though researchers of service quality admit that the measurement of service quality closely conforms to the disconfirmation paradigm (Bitner, Booms and Tetreault 1990; Bolton and Drew 1991) however these researchers suggest that service quality and satisfaction are distinct constructs. Cronin and Taylor (1992) suggested a definition of service quality as a form of "attitude and a long run overall evaluation" while satisfaction is a "transaction-specific measure". Students' satisfaction is becoming widely accepted by the higher education community as a significant factor to the academic institutions strategic interests. Students with higher satisfaction levels are more likely to reflect a positive image about the university and recommend the university to other potential students which would enhance the university competitiveness among other tertiary education institutions (Jiewanto, Laurens and Nelloh 2012). Students' satisfaction with their university not only contributes to the university's image and reputation it contributes significantly to the students' educational achievement (El Ansari \& Oskrochi 2006). A student who is satisfied with his/ her courses, teachers or university services would feel proud to be a student of that particular institution, would recommend it to other potential students or even return to the same institution if considered furthering his/ her education. This is well supported in the literature which suggests that students' feedback is a vital element in the quality improvement and student satisfaction (Harvey 1997; Kanji and Tambi 1999; Williams \& Cappuccini- Ansfield 2007; Houston 2008). Service Quality is a well established prerequisite for maintaining a strong and positive relationship with the customers (Young and Varble 1997). In a higher education context; the students' perceptions of the service quality at their universities is both significant and strategic to the students' current and future relationship to the university (Cronin and Taylor, 1992). Spreng and Mackoy (1996) identified perceived service quality as an antecedent to satisfaction. Lassar Manolis and Winsor (2000) suggested that there should be a proper "understanding of the determinants of customers' satisfaction". This understanding has a tremendous monetary value for the service organization in a competitive environment (Abu Hasan, Ilias, Rahman and Abd Razak 2008). The study by Bigne, Moliner and Sanchez (2003) found that satisfaction is highly influenced by overall service quality. Ham and Hayduk (2003) in their study of higher educational settings confirmed the presence of a positive correlation between perception of service quality and student satisfaction.

\subsection{Relation between Service Quality, Students Satisfaction and Behavioural Intentions}

It is very important to understand the students' behavioural intentions. The emphasis on students' behavioural intentions contributes to the profitability of loyal customers (Minami \& Dawson, 2008). Studies in the field of consumer satisfaction suggest that as a consequence of satisfaction individuals exhibit both attitudinal and 
behavioural intentions towards the products or service (Andreasen 1977; Day 1977). Students' loyalty intentions are also known as the word of mouth intention. Word of mouth intentions are formed from two famous concepts and these are word of mouth (WOM) and behavioural intentions (Jiewanto et al., 2012). Word of mouth intentions are characterized as oral, person-to-person communication between a receiver and a communicator whom the receiver perceives as non-commercial, regarding a brand, product or service (Arndt 1967). They signal the customer's willingness to recommend the service to other prospect customers in the near future (Dabholkar Shepherd and Thorpe 1995). Student satisfaction is also generally assumed to be a significant determinant of positive word-of mouth, retention and loyalty (Temizer \& Turkyilmaz 2012). The students' loyalty intentions and satisfaction with the service level at their universities are strongly inter-related to each other. The concepts of students' satisfaction and loyalty have become one of the major goals of all educational institutions. Naik, Krishna and Gantasala, (2010) emphasize that the service quality and customer satisfaction are antecedent to behavioural intentions. In other words when the students are satisfied with the service level at their universities they are most likely will recommend the university to other prospect students. Of the other factors which contribute to influence the students' behavioural intentions is the university image (Chung, Thorndike and Hwang 2009; Lin \& Lin, 2007; O’Cass \& Lim, 2010).

\subsection{The Palestinian Higher Education Sector}

The Higher Education system in the Palestinian territories refers to the educational system governing the tertiary education institutions in the West Bank and Gaza Strip. The system is a mixture of approaches "used in the United States, the United Kingdom, and France" (Taweel 2007). Today the Palestinian higher education system is comprised of 49 accredited post-secondary education institutions distributed between the West Bank and Gaza Strip. 34 of these institutions are located in the West Bank which range between traditional universities, university colleges, community colleges and an open university $(13,15,20$ and one respectively). They offer nearly 300 fields of study to some $(21,3973)$ students, $57 \%$ of whom are females. These institutions provide programs that range from Education, Arts and Humanities to Natural and Medical Sciences, ICT and Engineering (MOHE. 2011). While the statistics seems encouraging, however the study by BirZeit University (2010) suggests that the numbers are deceptive. According to the study the courses offered at the universities suffer from considerable homogeneity; therefore despite the existence of 247 post secondary programs, however these programs does not necessarily reflect the needs of the local economy or the interests of the students.

Taweel (2007) identified two main categories of studies which influence our understanding of the Palestinians higher education sector nowadays. The first category consists of compilation of raw data aggregated by nongovernmental agencies such as the United Nations and the World Bank as well as the annual statistics report issued by the Palestinian Ministry of Higher Education. The second category of studies consists of sporadic studies conducted by individual researchers. Both categories of studies focus on easily quantifiable variables such as the numbers and types of tertiary education institutions, the students versus teacher ratios, students' access to higher education, female participation wither as students or as faculty members and the number of full time versus part time academicians. While these studies provide some insight into the status and provision of higher education in Palestine, however they do not provide a holistic image of all aspects of higher education quality in the country.

The Palestinian universities are predominantly nongovernmental institutions; which are referred to as public; "a term that describes their establishment under a public law, not to their type of funding or governance" (Abu-Lughod 2000). The Palestinian Ministry of Higher Education (MOHE) refers to the universities in its annual statistics report as "Traditional" universities, which include public universities, governmental universities and private universities. The signing of the Oslo accords and the consequence establishment of the first Palestinian Ministry of Higher Education in 1998 provided a platform for them to finally flourish. New facilities were erected, more professors are hired and new programs and modes of study are integrated to the system, paralleled with unprecedented number of students obtaining their higher education at their local universities. Gerner and Shrodt (1999) explain how the Palestinians are "among the best educated in the postcolonial world.... considering the difficult conditions under which the Palestinian higher education system has been operating". Unfortunately this rapid expansion, though a necessity, threatens to render the provision of quality education in Palestine. A few recent studies suggest that the Palestinian higher education sector nowadays is in dire need of further attention in order not to lose yesterday gains.

The study by Hashweh M. Hashweh M. and Berryman (2003) assessed higher education needs in the West Bank and Gaza Strip and identified five fields that require further investigation which are access \& capacity, equity, quality, relevance and governance. The study concludes that the quality of higher education in most universities in Palestine seems to be in a state of decline, where the student versus teacher ratio is increasing, the percentage 
of part time teachers is increasing and the faculty academicians are overloaded. The study by BirZeit University in 2010, analyzes the Palestinian education system dichotomous role in socializing young people into society including preparing them for their future societal roles and selecting them into occupational structure based on their individual achievements. The study identifies key gaps in the education system preparation of students for the labour market. Among these gaps is the pedagogy of teaching system at the secondary level which was found to be restrictive in terms of skills development. The problem, according to the study, intensifies at the tertiary level with the lack of work based learning either through weak uptake of Technical and Vocational, Education and Training (TVET) or work-based study at the university and concludes that the education system in Palestine does not prepare the students with adequate soft and hard skills for the labour market. In 2010 the national study of undergraduate teaching practices in Palestine by Cristillo revealed insightful findings with regards to the quality of undergraduate education in the Palestinian Higher Education Institutions. The study revealed prevailing teacher- centred approach to learning vis-à-vis students centred approach, the failure of universities to adequately integrate the classroom into a more cohesive community and culture of learning and a growing concern among teachers, students and parents that university education is no longer relevant to the labour market (Cristillo, L. 2010).

The World Bank report on Equity and Access to Tertiary Education in the Middle East and North Africa Region in 2009 identified Palestine among the countries with the highest proportions of private enrolment in the region. According to the report "the youth bulge placed considerable demands on primary and secondary schools and ... on colleges and universities". The study highlighted the many challenges which face the Palestinians with relation to the socioeconomic profile of its students such as "the geopolitical situation, and the population boom among college-age Palestinians". The report also explains the many challenges faced by the Palestinian higher education institutions and the Palestinian professors to satisfy the increasing demand on their education while maintaining high standards for the programs they offer(World Bank 2009).

The study Daoud (2005) of the gender gap in returning to school in Palestine provided estimates of the private returns to schooling in Palestine utilizing eight quarterly labour force surveys for 1999 and 2001. The study investigated the differential impact of the Israeli closure policy on Palestinian male and female workers. The study concluded that returns to schooling are larger for women. The gap in returns to schooling was reduced in 2001; however, female returns to schooling suffer from selectivity bias which worsened during 2001. The females' marginal return was found almost twice as large as male marginal return. The schooling premium for 13-15 years of schooling is $10.6 \%$ and for the 16 or more years of schooling was $25 \%$ for 1999 . The Intifada affected the schooling premium negatively for both groups, but more so for the group with 16 or more years of schooling.

Despite the few attempted studies, self and external assessments by Palestinian universities and the governmental bodies as well as International Agencies, however these attempts seem to primarily focus on tangible aspects of higher education such as; access to education, equity, female participation, students versus teacher ratios and finally the number of full time and part time academic staff. Moreover, while these studies aim to enhance our understanding of the Palestinian higher education system achievements and shortfalls, which would necessarily influence the students, however with the exception of the study by Cristillo (2010) none of them take into account the Palestinian students' opinion in the education provided to them. The students come in contact with their institutions in various ways and at multiple occasions. Each time a student encounters a service, requests a documents from a department, arranges an appointment with a staff member, or simply checks a book out from the library he/she constructs a behavioural and attitudinal intention towards that person or department in particular and towards the institution as a whole. These occasions when the students come in contact with the institution are what should be examined in order to measure the students' perceptions, satisfaction and intentions towards their institution. This raises the need for studies which focus on measuring less tangible aspects of university education such as the service quality at the universities as recounted by the students. The literature neither yielded any prior studies which measure the service quality in Palestine Universities nor studies which measure the students' perceptions.

\section{Method}

\subsection{Study Background}

The study focus on two universities (named here; University A and University B) in the West Bank; Palestine. The two universities provide three levels of tertiary education. University A provides an undergraduate and a graduate program while University B provides a two years diploma and an undergraduate program. This study 
presents an assessment of the service quality in Palestine universities as perceived by their students utilizing the SERVQUAL gaps model.

\subsection{Population and Sample}

The study utilizes Krejcie and Morgan, 1970 equation to determine the sample size:

$$
S=\frac{x^{2} N P(1-P)}{d^{2}(N-1)+x^{2} P(1-P)}
$$

Where (s) the size of sample required, $\mathrm{N}$ is size of population, $\mathrm{P}$ is ratio of population (estimated as 0:50 to give the maximum sample size) and $\mathrm{d}$ is the degree of accuracy expressed as 12:05 $\mathrm{x}^{2}=$ chi-square value for 1 degree of freedom at 0.05 level (3841).

The participating universities provided the researcher with the total number of students attending their universities respectively: University A 7902, and University B 2968. Based on the aforementioned equation the total sample size is 375 respondents.

The data made available to this study was gathered through questionnaire administered to1200 students in a random manner in order ensure reaching the intended number of surveys; later only fully answered surveys were considered for further analysis. The students were assured to the confidentiality of their answers; therefore their names were not included in the survey format. The data was collected during the first week of May 2012 and the data from both universities was later combined together and considered representative of traditional universities in West Bank; Palestine as it ensured representation of respondents for the following reasons: the two universities combined provide three levels of study (two year diploma; an undergraduate program and a graduate program); the two universities are located in two different locations in the West Bank and they both receive students from different parts of Palestine including cities; towns and refugee camps.

\subsection{Survey Instrument Development}

The study adopted the survey instrument from the work of Tan and Kek 2004. Tan and Kek (2004) designed the survey instrument specifically for use by a university through parallel review of educational service indicators from the work of Kwan and Ng (1999) and from Harvey (2002). Tan and Kek (2004) described the development of the current survey model as follows: In 1970, Betz, Klingensmith \& Menne designed a survey instrument to measure service quality in education. The authors focused on educational support services and student encounters. Later in (1993) Hampton refined and condensed Betz et al. (1970) survey in order to "identify the different factors that contribute towards a quality education". The prime focus of Hampton's (1993) research was to develop "service indicators" by the students themselves. Hampton (1993) framed his questions in the form of a SERVQUAL survey which was carried out in the United States. In (1999) Kwan and Ng adopted the quality indicators developed by Hampton (1993). The authors argued that students' perceptions and expectations are often influenced by their cultural orientation. The authors considered cultural variables in service quality in their adaptation. Later Kwan and Ng (1999) conducted their survey in Hong Kong and China.

Meanwhile, Harvey and his associates conducted a parallel review at the Centre for Research into Quality (CRQ) at the University of Central England and latterly at the Centre for Research and Evaluation (CRE), Sheffield Hallam University (Harvey, 2002). Harvey's extensive review yielded the 'Student Satisfaction' model which has evolved over 14 years. The authors designed the model to be an effective tool to obtain, analyse, and report on students' views about their total university experience. A prime consideration of their research was the development of the service indicators by the students themselves. In 2004, Tan and Kek conducted parallel review of the educational service indicators from the work of Kwan and $\mathrm{Ng}$ (1999) and from the student satisfaction model by Harvey (2002) and combined the two lists of service quality attributes. Tan and Kek (2004) later tested the list from both reported studies on a pilot group of students. The results from the pilot test revealed 19 duplicative attributes which were later removed. The final result was a questionnaire instrument with 76 attributes. In line with SERVQUAL model, Tan and Kek (2004) constructed the 76 attributes of the survey to ask students to rate their expectations (E) and perceptions (P) of the educational service attributes.

\subsection{Validity and Reliability of the Survey Instrument}

The research took place in Palestine; where the spoken language is Arabic; therefore the researcher translated the questionnaire from English into Arabic language. In order to validate the translation, a back- to back translation was conducted and amendments were carried out.

A pilot test of the questionnaire was later introduced to students from the chosen Universities via email. 45 questionnaires were emailed to students from the participating universities. 21 complete copies were returned; 
ten from University A, and eleven from University B. The pilot test revealed one item that was confusing to the students; academic level. The researcher examined the internal consistency of the instrument using Cronbach alpha coefficient value using SPSS software. The Cronbach Alpha value was; 0.952 which exceeds the minimum level 0.7 recommended by Nunnally (1978)

\section{Results}

\subsection{The Participants Demographic Profile}

The survey initially asked students to identify four demographic attributes; gender; age; study level; and year of study. Three out of the four original attributes were selected for further analyses which are gender; age and study level. Year of study was dropped from further analysis since it would confuse the results. Table 1; summarizes the selected demographic attributes of the participants in this research

Table1. Selected demographic attributes of the survey respondents

\begin{tabular}{lll}
\hline & Frequency & Percent (\%) \\
\hline Gender & 181 & $48.3 \%$ \\
Male & 194 & $51.7 \%$ \\
Female & & \\
Study Level & 363 & $96.8 \%$ \\
Undergraduate & 9 & $2.4 \%$ \\
Postgraduate & 3 & $.8 \%$ \\
Two years diploma & & \\
Age & 23 & $6.1 \%$ \\
$<=18.00$ & 178 & $47.5 \%$ \\
$19.00-20.00$ & 152 & $40.5 \%$ \\
$21.00-22.00$ & 13 & $3.5 \%$ \\
$23.00-24.00$ & 4 & $1.1 \%$ \\
$25.00-26.00$ & 2 & $0.5 \%$ \\
$27.00-28.00$ & 3 & $0.8 \%$ \\
$29.00+$ &
\end{tabular}

The majority of the respondents who participated in the survey could be described as female; undergraduate students at the age 19 to 20 years old. The percentage of females who participated in the survey accounts for 51.7percent of the total population which is in parallel with the latest figures from the Palestinian ministry of Education and Higher Education statistics for the year 2010- 2011. According to the ministry for the academic year 2010/ 2011 the total number of newly enrolled students at the traditional universities in Palestine was 28, 592 students; out of them 58.58 percent were female students (MOHE. 2011). The majority of the respondents were undergraduate students accounting for nearly $97 \%$ of the students while only $2.4 \%$ of the total respondents were postgraduate students who were from University A and $0.8 \%$ were diploma students from University B. The statistics released from the Palestinian Ministry of Education and Higher Education for the academic year 2010/ 2011 corresponds with the researchers' statistics. For the year 2010/ 2011 the total number of enrolled students at West Bank Higher Education Institutions by scientific degree was 74267 students; out of whom 86\% were Bachelor students; 2.9 were Graduate students and $5.7 \%$ were two years Diploma students. The majority of the students surveyed were within the age group 19- 20 years old accounting for $47.5 \%$ followed by the age group 21- 22 years old which accounted for $40.5 \%$ both groups accounting for $88 \%$ of the total number of students surveyed.

\subsection{Pre-Evaluation: Principle Component Analysis}

To validate the instruments gap scores (perceptions minus expectations) a principle factor analysis utilizing Principle component analysis extraction method and VARIMAX rotation on all 375 surveys was conducted. 
Prior to performing PCA the suitability of the data for factor analysis was assessed. The correlation matrix revealed the presence of many coefficients of 0.5 and above. The Kaiser- Meyer value was 0.91 which exceeds the recommended value of 0.6 (Kaiser 1970, 1974) and Barlett's Test of Sphericity (Barlett 1954) reached statistical significance which supports the suitability of the correlation matrix. The results from the principle component analysis revealed the presence of five components. The five components solution explained $64.4 \%$ of the variance.

The original survey instrument included 75 statements collapsed into eight factors. Following the principle component analysis, statements with a loading less than 0.5 were dropped from further analysis. The resulted statements accounted for 52 statements within five factors. The majority of the statements were returned to their original groups however some statements loaded on different components.

Computing facilities and Library facilities were returned successfully to their original classifications. The students seemed to perceive learning; teaching and advising as one component resulting in a new factor named Educational Activities (Learning, Teaching and Advising).The students perceived Library facilities as well as the amount and availability of other university facilities similarly, in addition to one component from social activities "The campus events and activities that are provided for students". This could be attributed to the fact that some of the activities take place at the university library facilities. The resulting five factors are; Learning, Teaching \&Advising; Library facilities, Computing facilities, Assessment and University Facilities.

\subsection{Reliability Test}

The construct reliability using Cronbach's alpha coefficient was tested. Table 2 below summarizes the results from the construct reliability test; with the Cronbach alpha coefficient values. The results from the construct reliability test for the five constructs revealed a Cronbach alpha value which exceeds the ideal Cronbach's alpha coefficient value of 0.7 recommended by Nunnally (1978)

Table 2. Reliability test and Cronbach alpha coefficient values

\begin{tabular}{lll}
\hline \multicolumn{1}{c}{ Construct } & Cronbach Alpha values & No. Of Items \\
\hline Teaching, Learning \&Advising & 0.926 & 15 \\
Library Facilities & 0.930 & 14 \\
Computer Facilities & 0.803 & 9 \\
Assessment & 0.835 & 8 \\
University Facilities & 0.890 & 6 \\
\hline
\end{tabular}

\subsection{Importance of Educational Services Constructs}

The mean scores for students' expectations ranged from 5.24 to 5.43. The highest score registered to the construct "Library Facilities" (mean 5.43). The second most important category of education services was "Computer Facilities" (mean 5.37); followed by University Facilities (mean 5.37) and Teaching; learning and Advising (mean 5.33). The least important component for the students was Assessment (mean= 5.24) (see table $3)$.

Table 3. The mean scores for students' expectations

\begin{tabular}{ll}
\hline Construct & Mean Expected \\
\hline Learning, Teaching and Advising & 5.33 \\
Library Facilities & 5.43 \\
Computer Facilities & 5.37 \\
Assessment & 5.24 \\
University Facilities & 5.36 \\
\hline
\end{tabular}




\subsection{The Palestinian Students Satisfaction with the Educational Services}

The student's satisfaction with the educational services provided to them at their respected universities was tested where the students' were asked to rate their perception of the educational services on a seven points Likert scale. Table 4 demonstrates the results from the students' perceptions of the five educational service categories:

Table 4. Student's satisfaction with the educational services

\begin{tabular}{ll}
\hline Component & Mean Perceived \\
\hline Learning, Teaching and Advising & 4.75 \\
Library Facilities & 4.91 \\
Computer Facilities & 4.70 \\
Assessment & 4.75 \\
University Facilities & 4.89 \\
Construct overall satisfaction & 4.80 \\
\hline
\end{tabular}

The mean scores for students' perceptions ranged from 4.70 to 4.91 . The students were found to be very satisfied with all the educational services; learning, teaching and advising, library facilities; computer facilities, Assessment and university facilities. The lowest mean score registered for "computer facilities" (mean= 4.70) while the highest mean score was (mean= 4.91) registered for the "library facilities". The students' overall satisfaction with the educational services "Construct overall satisfaction" supported the findings where the results indicated high overall satisfaction with the educational services (mean $=4.80$ ).

\subsection{The Palestinian Students' Loyal Intentions}

The students were loyal to their universities $(\mathrm{Mean}=5.56$, S.D. $=1.50)$. The results of the frequencies of the numeric scores (summarized in Table5) indicate that the majority of the students who responded to the survey $(32.0 \%)$ are completely loyal to their respective universities compared to $(20.5 \%)$ who considered themselves as completely non-loyal. The following largest group of students accounting for (28.3\%) of the survey respondents considered themselves as loyal to their universities compared to $(7.2 \%)$ who considered themselves non- loyal to their universities. Only (12.0\%) of the respondents; considered themselves somehow loyal to their universities (see table 5).

Table 5. Palestinian Students' Loyal Intentions

\begin{tabular}{lll}
\hline Students Loyalty Intentions & Frequency & Percent \\
\hline Completely Loyal & 120 & $32.0 \%$ \\
Loyal & 106 & $28.3 \%$ \\
somehow Loyal & 45 & $12.0 \%$ \\
Non-loyal & 27 & $7.2 \%$ \\
completely non-loyal & 77 & $20.5 \%$ \\
Total & 375 & 100.0 \\
\hline
\end{tabular}

\subsection{Service Quality of Educational Services in West Bank; Palestine Universities}

The results from the analysis of the gap scores revealed that the most unsatisfactory component was "Computer Facilities" (mean $=-0.67$ ). The closest educational service to satisfaction was University Facilities (mean $=-0.46$ ) followed by Assessment (mean= -0.49), Library Facilities (mean= -0.51) and Teaching, Learning and Advising Services $($ mean $=-0.57)$ (see table 6$)$. 
Table 6. Results of the mean expected values; perceived values and gap scores

\begin{tabular}{llll}
\hline Component & Mean Expected & Mean Perceived & Gap Scores \\
\hline Learning, Teaching and Advising & 5.33 & 4.75 & -0.57 \\
Library Facilities & 5.43 & 4.91 & -0.51 \\
Computer Facilities & 5.37 & 4.70 & -0.67 \\
Assessment & 5.24 & 4.75 & -0.49 \\
University Facilities & 5.36 & 4.89 & -0.46 \\
\hline
\end{tabular}

\subsection{The Relationship between Demographic Attributes and Overall Satisfaction}

Gender and overall satisfaction: The results shows that there was no statistically significant difference in the overall satisfaction level between males $(\mathrm{M}=4.77, \mathrm{SD}=0.93)$ and females $(\mathrm{M}=4.83, \mathrm{SD}=0.86)$; $\mathrm{t}(373)=-0.56$, $\mathrm{p}=0.57$ (two- tailed). The magnitude of the difference between the males and females mean (mean difference= $0.9331,95 \%$ CI: -0.23 to 0.13 ) was very small (eta squared $=0.0008)$ Cohen $(1988,284-7)$.

Study Level and Overall satisfaction: The results from the analysis indicates that there was a statistically significant difference among the mean scores of the three subgroups at the $\mathrm{p}<.05$ level in overall satisfaction: $\mathrm{F}$ $(2,372)=7.76, p=.000$. However the magnitude of the difference in the means between the three subgroups is small to moderate (eta squared $=0.04$ ) which indicate small to moderate effect Cohen (1988).

Age and Overall Satisfaction: The results indicate a statistically significant difference at the $p<.05$ level in overall satisfaction for the seven subgroups: $\mathrm{F}(6,368)=2.089, \mathrm{p}=.054$. The magnitude of the difference in the means between the three subgroups (eta squared $=0.01$ ) indicates small effect Cohen (1988).

\subsection{The Relationship between Demographic attributes and Loyalty Intentions}

Gender and Students' loyalty intentions: The results concludes that there was no significant difference in the Students' intentions between males $(\mathrm{M}=5.71, \mathrm{SD}=1.53)$ and females $(\mathrm{M}=5.42, \mathrm{SD}=1.47)$; $\mathrm{t}(373)=1.834$, $\mathrm{p}=.068$ (two-tailed). The magnitude of the difference between the males and females mean (mean difference $=.285,95 \%$ CI: -.021 to .590 ) was very small (eta squared $=.008)$ (Cohen (1988).

Study Level and loyalty Intentions: The results indicates that there was statistically significant difference at the $\mathrm{p}<.05$ level in Students' for the three subgroups: $\mathrm{F}(2,372)=4.097, \mathrm{p}=.017$. The magnitude of the difference in the means between the three subgroups is small (eta squared $=0.021$ ) (Cohen (1988).

Age and Loyalty Intentions: The results indicate that there was statistically significant difference at the $\mathrm{p}<.05$ level in Students' for the seven subgroups: $F(6,368)=2.657, \mathrm{p}=.016$. The magnitude of the difference in the means between the three subgroups is small (eta squared $=0.041$ ) Cohen (1988).

Relationship between Overall Satisfaction and Loyalty Intentions: The results from the correlation test suggest that there is a strong positive correlation between the two variables, $r=+0.464 ; \mathrm{N}=375$; where high satisfaction is associated with high intentions. Students satisfaction explained $21 \%$ of the variance.

\section{Discussion}

The reliability test supported the strength of the constructs composing the survey instrument and thus the applicability of the SERVQUAL survey model to be used in the context of the Palestinian higher education sector.

The first analysis in the study aims to uncover which service constructs are the most important and thus desired by Palestine students. Given the current lack of knowledge of students' expectations in Palestine students, this is an explorative research study utilizing a modified SERVQUAL instrument to investigate which service constructs are the most anticipated by the students. The analysis of the students' important service constructs revealed that the students considered all service constructs very important to them. Yet, the most important service constructs to the students are "Library Facilities" followed by "Computer Facilities". The results indicate that the Palestinian students want the Library facilities at their universities to be convenient and provide adequate spaces for private and group studies which are updated with wide range of books and periodic journals. These services will expose the students in Palestine at a young age to the scholarly world and enhance their research skills. The second most important service construct to the students is the "Computer Facilities". The students want updated computers, reliable network and assistance on the use of these equipments. The integration of ICT into higher education is receiving wide acceptance. These technologies influenced tertiary education where 
lecturers are no longer the only source of information. The integration of "Computer networking" into the education process "promotes student autonomy, increases classroom equality, and help students develop a critical learning perspective" (Warschauer, Turbee and Roberts 1996). Further Andreson (2000) and Nixon, Beattie, Challis, and Walker (1998) argue that the relationship between teaching and research is highly influential. The research generates an added dimension to teaching and allows the development of a collaborative relationship between lecturer and students within a learning community. The Palestinian higher education serves an increasing number of students and with the physical and financial constraints imposed on both the faculty and the students which challenge the delivery of quality education these technologies together with modern well equipped libraries would assist the Palestinian higher education sector efforts to shift from teacher centred approach to a learner centred approach, which would consequently ease the burden of providing quality education with limited resources and overloaded faculty. The students rated the importance of the three remaining services constructs starting with "University Facilities", "Teaching; learning and Advising" and last with "Assessment". The students aspire for education that is relevant and broadens their horizons. They want lecturers who know their subjects well and are capable to advise them academically, who also have a clear and consistent assessment criteria. The students' expectations could also be influenced through enhancing the university image through media outlets such as education expos, offering scholarships for distinguished students and financial aid programs.

The results revealed that the students in Palestine universities are very satisfied with the service level. The most satisfactory service constructs are "Library Facilities" and "University Facilities". The students perceived the service level of "Assessment" and the service level of "Teaching, learning and Advising" similarly. The students perceived the service construct "Computing facilities" as the least satisfactory among the service constructs presented to them. The students overall perceived satisfaction with the service level is in parallel with the results from the students perceptions of the five constructs. The students' satisfaction in the service quality will contribute to retain the current students, attract future students, enhances the chances to engage current students and the university alumni in positive word of mouth recommendations for prospect students and maintains the universities positive image (Jiewanto et al 2012). Stakeholders across the higher education spectrum are advised to focus on factors that are not only related to the educational process if they wish to maintain their academic status and differentiate themselves from other institutions. The students' satisfaction with their university not only contributes to the university's image and reputation it contributes significantly to the students' educational achievement (El Ansari \& Oskrochi 2006).

The analysis of the service quality in West Bank; Palestine universities revealed that all five service constructs were negatively disconfirmed. The most negatively disconfirmed components are the "Computing Facilities" followed by "Learning, Teaching and Advising". The three remaining service constructs were ranked starting with "Library Facilities", "Assessment" and "University Facilities" which was the nearest service constructs to expectations. The results from service quality are interpreted as the students not receiving the same service level they expected from their universities.

The service quality is an antecedent to students' satisfaction therefore the universities are advised to improve the service level of the five components with special focus on the service constructs which require more attention than others. The "Computing Facilities" could be improved with more updated computers and printers. The facilities opening hours could be adjusted to be more convenient to the students. The staff should be trained, friendly and understanding of the students needs. The service construct "Teaching, Learning and Advising" is the second most unsatisfactory construct which warrants attention. This service construct could be enhanced with adopting an education approach that develops the students' soft and hard skills. A special course which focuses on developing the students' soft skills, such as communication skills, team work skills, debates and problem solving skills could be integrated into the study program as an elective course. The university should encourage building links with professionals and experts from the local market. These professionals could be invited to present their work or scientific experience from a practical point of view and engage in direct discussions with the students. These opportunities will enrich the students' academic and practical experience, facilitates their transition to employment through enhancing their knowledge of the job market demands. The results also suggest that a more direct and transparent relation between the university management and the students is in need of attentions. The university management should encourage direct and frequent communication channels with the students through students unions and other representative bodies. The students' suggestions and feedback should be taken into consideration when designing the universities plans; otherwise the gap between the university management and the students will increase. The universities are advised to conduct more focused research on the service quality of the each of the service constructs in order to identify good practices and build 
on them and service areas that need further attention. A dissatisfactory service quality will negatively influence the relation between the students and the universities, which would affect the universities monetary and strategic interests.

The results revealed that the majority of the students in West Bank; Palestine Universities are completely loyal to their universities followed by the second largest group of students who considered themselves as loyal to their universities. However one fifth of the students were found completely non- loyal to their universities. This percentage is reflected in the comment of one of the respondents who commented on the survey form with "Do we have any other options". When answering if they were proud of to be students of the respective university; one of the students commented with "only in front of students from other universities". Though the results seems to be encouraging however to have a fifth of the sample describing themselves as completely non loyal is not a small number. The sense of helplessness expressed in the students' comments warrens that the students attend the universities out of lack of choice or their inability to obtain their education elsewhere.

The students' loyalty to their university is very important to attract new students, and decrease the chances of students defecting to other institutions. The results from the students' loyalty analysis could not be interpreted in isolation from other elements in the study. The students' loyalty intentions and the students' satisfaction with the service level at their universities are strongly inter-related to each other. Student satisfaction is a significant determinant of positive word-of mouth recommendation, retention and loyalty (Temizer L., \& Turkyilmaz A. 2012). In other words when the students are satisfied with the service quality at their universities they are most likely to recommend it to other prospect students. The correlation between the students overall perceived satisfaction and the students' loyalty is strong which means that enhancing the students' satisfaction would contribute significantly to enhancing the students' loyalty intentions. Yet a further investigation into the other potential factors such as the university image which might contribute to enhancing the students' loyalty is recommended.

The students' satisfaction and loyalty intentions are influenced by age and study level however gender did not have an impact in both cases. Studies have shown a strong relation between satisfaction and age (eg. Salanova, Agut, and Peiro 2005, Realo \& Dobewall 2011). The students' overall satisfaction is highly correlated the students' loyalty intentions which is supported in the literature (e.g., Athiyaman 1997). The study revealed that the older the students the more they are satisfied and loyal. The students' satisfaction with the university determines their decision to persist pursuing their education at that university. Students tend to take the decision to transfer to other institutions normally during the first and second year of study. Studies show that not all students who enter a university have the intention to obtain the degree. The students' decision to finish their degree depends on several factors such as ability, aspirations secondary school grades and socioeconomic status (Astin 1977). Students who choose to finish their education at the academic institution reflect their persistence and satisfaction with their academic choice. The universities should realize the importance of students' demographic attributes which influence their perceptions of the service quality. These factors should be taken into consideration when planning to enhance the students' satisfaction which would influence their loyalty and behavioural intentions.

\section{Conclusion and Recommendations for Further Studies}

While education in general and higher education in particular continues to play major role in the life of the Palestinians; the current study shed light on the current service quality in Palestine higher education. The study focused on several service quality aspects in higher education which are considered a priority by the students who are the prime customer of these services. The study also focused on students' perceptions of the current status of service in West Bank; Palestine universities. The results call upon faculty, staff and the universities' administration to increase their efforts to meet the expectations of the students and meet their needs. The SERVQUAL gaps model and the survey instrument proved to be convenient instrument to be tested in an Arab educational context. The discrepancy in the students' expectations and perceptions reflects on service gaps from the university side. A more concrete research into the students' expectations as well as direct and frequent relationship with the students would tremendously enhance the university understanding of the students' needs and perceptions of the service level. These could be done through online surveys of the service level through the university internal network, suggestions boxes at all service encounters and frequent monitoring and benchmarking the service constructs. With modern technologies, these evaluations could be conducted at very low costs. The university employees and work systems should also be further studied to identify poor approaches. Employees who do not feel appreciated, who are overloaded with tasks, which have to work with poor support systems or simply not trained and empowered enough to carry the tasks will not perform well. These are the internal customers of the university, and the face which the students would build their impressions on when they 
recall their university life. The university should invest in them through updated support services, comprehensive empowering plan which enhance their skills and abilities as well as a management system which commends them for the work they do and help them overcome their shortfalls. Due to the physical and financial limitations; the study focused only on traditional universities in the West Bank; Palestine. Further studies should be conducted to include other post secondary education institutions such as private institutions; university colleges and community colleges both in the West Bank as well as in Gaza Strip in order to form a more precise opinion of the service quality status in post secondary institutions in Palestine.

\section{Acknowledgement}

The authors of this research would like to thank Professor Dr. Kay C. Tan, The National University of Singapore for his most valuable contribution to the study.

\section{References}

Abu Hasan, H. Ilias, A. Rahman, \& R. Abd Razak M. (2008). Service Quality and Student Satisfaction: A Case Study at Private Higher Education Institutions. International Business Research. Retrieved from http://ccsenet.org/journal/index.php/ibr/article/view/982/952

Abu-Lughod, Ibrahim A. (2000). Palestinian Higher Education: National Identity, Liberation, and Globalization. Boundary, 2, 7595. http://dx.doi.org/10.1215/01903659-27-1-75

Andreasen, A. R. (1977). A Taxonomy of Consumer Satisfaction/ Dissatisfaction Measures. Towards a Process Model of Consumer Satisfaction in conceptualization and measurement of Consumer Satisfaction and Dissatisfaction. H. Keith Hunt, ed. Cambridge, Massachusetts: Marketing Science Institute.

Andreson, L. (2000). "Teaching development in higher education as scholarly practice: a reply to Rowland et al. turning academics into teachers". Teaching in Higher Education, 5(1), 23-31. http://dx.doi.org/10.1080/135625100114939

Arndt, J. (1967). Word of mouth advertising: A review of the literature. Advertising Research Foundation

Astin, A. W. (1993). What matters in college? Four critical years revisited. Jossey-Bass San Francisco.

Athiyaman, A. (1997). Linking student satisfaction and service quality perceptions: the case of university education. European Journal of Marketing, 31(7), 528-540. http://dx.doi.org/10.1108/03090569710176655

Awan M., \& Mahmood K. (2011). Development of a service quality model for academic libraries. Quality \& Quantity, 1-11. http://dx.doi.org/10.1007/s11135-011-9587-x

Bai, C., \& Liu, C. (2002). Customer loyalty and its determinants for service firms. Nankai Business Review, 64-69.

Barlett, M. (1954). A note on the multiplying factors for various chi square approximations. Journal of the Royal Statistical Society, 16, 296-298.

Betz, E. Klingensmith, J., \& Menne, J. (1970). The measurement and analysis of college student satisfaction. Measure and Evaluation in Guidance, 32, 110-118.

Bigne, E., Moliner, M. A., \& Sanchez, J. (2003). Perceived quality and satisfaction in multiservice organizations: the case of Spanish public services. Journal of Services Marketing, 17, 420-442. MCB UP Ltd http://dx.doi.org/10.1108/08876040310482801

BirZeit University. (2010). Improving the Flow of Information between Universities, Youth, and the Labor Market to Enhance Learning and Development of the Workforce. Centre for Development Studies, BirZeit University. Retrieved October 2011, from http:/home.birzeit.edu/cds/publications/2010/flowe.pdf

Bitner, M. J., Booms, B. H., \& Tetreault, M. S. (1990). The service encounter: diagnosing favorable and unfavorable incidents. The Journal of Marketing, 71-84. http://dx.doi.org/10.2307/1252174

Bolton, R. N., \& Drew, J. H. (1991). A multistage model of customers' assessments of service quality and value. Journal of consumer research, 375-384. http://dx.doi.org/10.1086/208564

Brysland, A., \& Curry, A. (2001). Service improvements in public services using SERVQUAL. Managing Service Quality, 11(6), 389-401. http://dx.doi.org/10.1108/09604520110410601

Buzzell, R. D., \& Gale, B. T. (1987). The PIMS Principles: Linking Strategy to Performance. The Free Press, New York, NY. PMCid:1054194 
Chen S. (2012). The establishment of a quality management system for the higher education industry. Quality \& Quantity, 46, 1279-1296. http://dx.doi.org/10.1007/s11135-011-9441-1

Chua, C. (2004). Perception of quality in higher education, In Carmichael, R. (Ed.) Quality in a time of change. AUQA occasional publication, Proceedings of the Australian Universities Quality Forum, 4, 181-187.

Chung Jae-Eun, Pysarchik Dawn Thorndike, \& Sun-Jin. Hwang. (2009). Effects of Country-of Manufacture and Brand Image on Korean Consumers' Purchase Intention. Journal of Global Marketing, 22, 21-41. http://dx.doi.org/10.1080/08911760802511352

Cohen, J. W. (1988). Statistical Power analysis for the behavioral science. Hillsdale, NJ: Lawrence Erlbaum Associates.

Cristillo L. (2010). National Study Of Undergraduate Teaching Practices In Palestine. United States Agency For International Development cooperative Agreement No. 294-A-00-05-0023400. Retrieved from http://www.aqac.mohe.gov.ps/EngV/Aqac_Index/AQACfiles/pub/PFDP\%20Report\%20Final\%20419.pdf

Cronin, J., Michael, J. Brady, K., \& Thomas, G. Hult, M. (2000). Assessing the effects of quality. value, and customer satisfaction on behavioural intention in service environment. Journal of Retailing, 76(2), 193-218. http://dx.doi.org/10.1016/S0022-4359(00)00028-2

Cronin, J. J., \& Taylor, S. A. (1992). Measuring service quality: a re-examination and extension. Journal of Marketing, 56(3), 55-68. http://dx.doi.org/10.2307/1252296

Dabholkar, P. A., Shepherd, C. D., \& Thorpe, D. I. (2000). A comprehensive framework for service quality: an investigation of critical conceptual and measurement issues through a longitudinal study. Journal of Retailing, 76, 139-173. http://dx.doi.org/10.1016/S0022-4359(00)00029-4

Daoud Y. (2005). Gender gap in returns to schooling in Palestine Department of Economics, Birzeit University. Economics of Education Review, 24, 633-649. http://dx.doi.org/10.1016/j.econedurev.2004.09.007

Day, R. L. (1977). Towards a Process Model of Consumer Satisfaction in conceptualization and measurement of Consumer Satisfaction and Dissatisfaction. In H. Keith Hunt (Ed.), Cambridge, Massachusetts: Marketing Science Institute.

De Jager J., \& Gbadamosi G. (2010). Specific remedy for specific problem: measuring service quality in South African higher education. Higher Education. http://dx.doi.org/10.1007/s10734-009-9298-6

El Ansari W., \& Oskrochi R. (2006). What matters most? Predictors of student satisfaction in public health educational course. Journal of the royal institute of public health, 120, 462- 473

Gatfield, T., Barker, M., \& Graham, P. (1999). Measuring Student Quality Variables and the Implications for Management Practices in Higher Education Institutions: an Australian and international student perspective. Journal of Higher Education Policy and Management, 21(2), 239-252 http://dx.doi.org/10.1080/1360080990210210

Gerner D. J., \& Schrodt P. A. (1999). Into the New Millennium: Challenges Facing Palestinian Higher Education in the Twenty-first Century. Arab Studies Quarterly, 21(4), 17 - 33.

Grönroos C. (1990). Relationship approach to marketing in service contexts: The marketing and organizational behavior interface. Journal of business research, 20(1), 3-11. http://dx.doi.org/10.1016/0148-2963(90)90037-E

Grönroos C. (1999). Internationalization strategies for services. Journal of Services Marketing, 13(4/5), 290-297. http://dx.doi.org/10.1108/08876049910282547

Ham, L., \& Hayduk, S. (2003). Gaining Competitive Advantages in Higher Education: Analyzing the Gap between Expectations and Perceptions of Service Quality. International Journal of Value-Based Management, 16, 223-242. http://dx.doi.org/10.1023/A:1025882025665

Hampton, M. (1993). Gap analysis of college student satisfaction as a measure of professional service quality. Journal of Professional Services Marketing, 9(1), 369-380. http://dx.doi.org/10.1300/J090v09n01_10

Harvey, L. (1997). The Student Satisfaction Manual. Buckingham, Open University Press/Society for Research into Higher Education.

Harvey, L. (2002). 'Student feedback: a report to the higher education funding council for England'. Retrieved from http://www.uce.ac.uk/crq/publications/studentfeedback.pdf 
Hashweh M., Hashweh M., \& Berryman S. (2003). An Assessment of Higher Education Needs in the West Bank and Gaza. United States Agency for International Development (USAID). Retrieved from http://pdf.usaid.gov/pdf_docs/Pnacw688.pdf

Houston, D. (2008). Rethinking quality and improvement in higher education. Quality Assurance in Education, 16, 61-79. http://dx.doi.org/10.1108/09684880810848413

Jiewanto A., Laurens, C., \& Nelloh, L. (2012). Influence of Service Quality, University Image, and Student Satisfaction toward WOM Intention: A Case Study on Universitas Pelita Harapan Surabaya. Procedia-Social and Behavioral Sciences, 40, 16-23. http://dx.doi.org/10.1016/j.sbspro.2012.03.155

Kaiser, H. (1970a). A second generation Little Jiffy. Psychometrika, 35, 401-415 http://dx.doi.org/10.1007/BF02291817

Kaiser, H. (1974b). An index of factorial simplicity. Psychometrika, 39, 31-36. http://dx.doi.org/10.1007/BF02291575

Kanji, G. K., \& Tambi, A. M. B. A. (1999). Total quality management in UK higher education institutions. Total Quality Management, 10(1), 129-153. http://dx.doi.org/10.1080/0954412998126

Kessler, S. (1995). Total quality service: a simplified approach to using the Baldrige award criteria. ASQC Quality Press, Milwaukee.

Krejcie, R., \& Morgan D. (1970). Determining sample size for research activities. Educational and Psychological Measurement, 30, 607-610.

Kwan, P., \& Ng, P. (1999). Quality indicators in higher education: comparing Hong Kong and China students. Managerial Auditing Journal, 14(1), 20-27. http://dx.doi.org/10.1108/02686909910245964

Lassar, W. M., Manolis, C., \& Winsor, R. D. (2000). Service quality perspectives and satisfaction in private banking, Journal of Service Marketing, 14(3), 244-271. http://dx.doi.org/10.1108/08876040010327248

Lin Nan-Hong, \& Lin Bih-Shya. (2012). The Effect of Brand Image and Product Knowledge on Purchase Intention Moderated by Price Discount. Journal of International Management Studies. http://dx.doi.org/10.1016/j.sbspro.2012.03.155

Lovelock C. (1981). Why Marketing Management Needs to be Different for Services". Marketing of Services, J. Donelly and W. George, eds., Chicago: American Marketing, 5-9.

Naik, C. N, Krishna, G. S. B., \& Gantasala, V. P. (2010). Service quality (SERVQUAL) and its effect on customer satisfaction in retailing. European Journal of Social Sciences, 16, 231-243.

Nixon, J., Beattie, M., Challis, M., \& Walker, M. (1998). "What does it mean to be an academic? A colloquim". Teaching in higher Education, 3(3), 277- 98. http://dx.doi.org/10.1080/1356215980030301

Nunnally, J. (1978). Psychometric theory. New York: McGraw- Hill.

O'Cass A., \& Lim K. (2001). The influence of brand associations on brand preference and purchase intention: An Asian perspective on brand associations. Journal of International Consumer Marketing, 14(2/3), 41-71. http://dx.doi.org/10.1300/J046v14n02_03

Palestinian Ministry of Higher Education. (2011). Palestinian Higher Education Statistics 2010 2011. Retrieved July 15, 2012, from http://www.mohe.gov.ps/Uploads/admin/Matweyeh2011.pdf

Parasuraman, A., Zeithaml, V., \& Berry, L. (1988). SERVQUAL: a multiple-item scale for measuring consumer perceptions of service quality. Journal of Retailing, 64(1), 12-40.

Parasuraman, A., Zeithaml, V., \& Berry, L. (1985). A conceptual model of service quality and its implications for the future research. Journal of Marketing, 49(4), 41-50. http://dx.doi.org/10.2307/1251430

Realo, A., \& Dobewall, H. (2011). Does life satisfaction change with age? A comparison of Estonia, Finland, Latvia, and Sweden: Journal of Research in Personality, 45(3), 297-308. http://dx.doi.org/10.1016/j.jrp.2011.03.004

Reeves, C., \& Bednar, D. (1994). Defining Quality: Alternatives and Implications. The Academy of Management Review, 19(3), 419-445. http://dx.doi.org/10.5465/AMR.1994.9412271805

Sahney, S. Banwet, D., \& Karunes, S. (2004). A SERVQUAL and QFD approach to total quality education:A student perspective. International Journal of Productivity and Performance Management, 53(2), 143-166. http://dx.doi.org/10.1108/17410400410515043 
Salanova, M., Agut, S., \& Peiro, J. (2005). Linking organizational resources and work engagement to employee performance and customer loyalty: the mediation of service climate. Journal of Applied Psychology, 9(6), 12-17. http://dx.doi.org/10.1037/0021-9010.90.6.1217

Shekarchizadeh, A. Rasli, A., \& Hon-Tat, H. (2011). SERVQUAL in Malaysian universities: perspectives of international students. Business Process Management Journal, 17(1), 67-81. http://dx.doi.org/10.1108/14637151111105580

Soutar G., \& McNeil M. (1996). Measuring service quality in a tertiary institution. Journal of Educational Administration, 34(1), 72-82. http://dx.doi.org/10.1108/09578239610107174

Spreng, \& Mackoy, R. D. (1996). An empirical examination of a model of perceived service quality and satisfaction. Journal of Retailing, 72(2), 52-64. http://dx.doi.org/10.1016/S0022-4359(96)90014-7

Tan, K., \& Kek, S. (2004). Service quality in Higher Education using an enhanced SERVQUAL approach. Quality in Higher Education, 10(1), 17-24. http://dx.doi.org/10.1080/1353832242000195032

Taweel H. (2007). The Academic Profession In Palestine: A survey. Boston College, Lynch School Of Education. Department Of Educational Administration/Higher Education Higher Education Administration. Retrieved from http://proquest.umi.com/pqdweb?did=1490085761\&sid=1\&Fmt=2\&clientId=79356\&RQT=309\&VName= PQD

Temizer L., \& Turkyilmazb, A. (2012). Implementation of student satisfaction index model in higher education institutions. Procedia - Social and Behavioral Sciences, 46, 3802-3806. http://dx.doi.org/10.1016/j.sbspro.2012.06.150

Warschauer, M., Turbee, L., \& Roberts, B. (1996). Computer learning networks and student empowerment. System, 24, 1-14. http://dx.doi.org/10.1016/0346-251X(95)00049-P

Williams, J., \& Cappuccini-Ansfield, G. (2007). Fitness for purpose? National and institutional approaches to publicising the student voice. Quality in Higher Education, 13, 159-172. http://dx.doi.org/10.1080/13538320701629186

Young, J., \& Varble, D. (1997). Purchasing's performance as seen by its internal customers: a study in a service organization. Journal of Supply Chain Management, 33(3), 36-41. http://dx.doi.org/10.1111/j.1745-493X.1997.tb00030.x

Zeithaml, Valarie A., Bitner, \& Mary J. (1996). Service Marketing. McGraw-Hill.

Zhang, R., Li, X., \& Yunchang Zhang. (2010). Service quality, customer satisfaction And customer loyalty of mobile communication industry in china. Journal of Global Academy of Marketing Science, 20(3), 269-277. http://dx.doi.org/10.1080/12297119.2010.9707353 